\title{
The Productivity of Spring Wheat when Using Biological Drugs and Organic Fertilizers
}

\author{
Galina Saidyasheva* and Sergey Nikitin \\ Ulyanovsk Research Institute of Agriculture - branch of Sam SC RAS, 43315, Timiryazevsky, Ulyanovsk district, Ulyanovsk region, \\ Russia
}

\begin{abstract}
The studies were carried out with the aim of developing recommendations for the environmentally safe and effective use of organic fertilizers and increasing the productivity of grain-fallow crop rotation in the landscape agriculture in the Volga region. The effectiveness of organic fertilizers and biological products was studied on the experimental field of Ulyanovsk Research Institute of Agriculture. The crop rotation involved the 7-field grain-fallow with the following alternation of crops: pure fallow winter wheat - spring wheat - peas - winter wheat - spring wheat - barley. The repetition was fourfold, the plot area was $100 \mathrm{~m}^{2}$. Meteorological conditions were favorable, the hydrothermal coefficient was 1.1-1.2. The experiment scheme included the following options: 1 - without fertilizers (control); $2-\mathrm{N}_{140} \mathrm{P}_{95} \mathrm{~K}_{175}$ (equivalent to $25 \mathrm{t} / \mathrm{ha}$ of manure); 3 - manure, $25 \mathrm{t} / \mathrm{ha} ; 4$ - manure, $50 \mathrm{t} / \mathrm{ha} ; 5$ - sewage sludge in a dose equivalent to $25 \mathrm{t} / \mathrm{ha}$ of manure (OSV-1); 6 - sewage sludge in a dose equivalent to $50 \mathrm{t} / \mathrm{ha}$ of manure (OSV-2); 7 - green manure (equivalent to 25 t/ha of manure); 8 - straw, 5 t/ha $+\mathrm{N}_{115}$ (equivalent to 25 t/ha of manure); 9 - pre-sowing treatment of seeds with Rhizoagrin (background); 10 - background + $\mathrm{N}_{140} \mathrm{P}_{95} \mathrm{~K}_{175}$ (equivalent to $25 \mathrm{t} / \mathrm{ha}$ of manure); 11 - background + manure, $25 \mathrm{t} / \mathrm{ha} ; 12$ - background + manure, 50 t/ha; 13 - background + OSV-1; 14 - background + OSV-2; 15 - background + siderat; 16 background + straw, $5 \mathrm{t} / \mathrm{ha}+\mathrm{N}_{115}$ (equivalent to $25 \mathrm{t} / \mathrm{ha}$ of manure). Studies have established that organic fertilizers and pre-sowing treatment of seeds with Rhizoagrin increase the accumulation of stubble-root residues, straw, nitrogen content and yield of spring wheat. The greatest input of nutrients into the soil with POC and high productivity of spring wheat were facilitated by the aftereffect of sewage sludge and manure in increased doses in combination with pre-sowing seed treatment with Rhizoagrin.
\end{abstract}

\section{Introduction}

In recent years, due to poor soil fertility, studies aimed at optimizing the mineral nutrition of plants under the limited use of fertilizers, revealing the duration of effects of fertilizers, assessing the role of biological factors in the reproduction of soil fertility are relevant $[1,2]$.

An analysis of literature shows that the problem of regulating the fertility of chernozems and crop yields in the Middle Volga region has been insufficiently studied. Very few long-term studies on the effect of fertilizers and biological products on the crop productivity and soil properties have been conducted. Meanwhile, the role of these factors is extremely important [3-9].

The present research was conducted with the aim of developing recommendations for the environmentally safe and effective use of organic fertilizers and increasing the productivity of grain-fallow crop rotation in the landscape agriculture of the Volga region.

\section{Materials and methods}

The effectiveness of organic fertilizers and biological products in grain-fallow crop rotation was studied on the experimental field of Ulyanovsk Research Institute of Agriculture.

The research was carried out in a seven-pole grainfallow crop rotation: pure fallow - winter wheat spring wheat - peas - winter wheat - spring wheat barley.

The experiment scheme included the following options: 1 - without fertilizers (control); $2-\mathrm{N}_{140} \mathrm{P}_{95} \mathrm{~K}_{175}$ (equivalent to $25 \mathrm{t} / \mathrm{ha}$ of manure); 3 - manure, $25 \mathrm{t} / \mathrm{ha}$; 4 - manure, $50 \mathrm{t} / \mathrm{ha} ; 5$ - sewage sludge at a dose equivalent to $25 \mathrm{t} / \mathrm{ha}$ of manure (OSV-1); 6 - sewage sludge at a dose equivalent to $50 \mathrm{t} / \mathrm{ha}$ of manure (OSV2); 7 - green manure (equivalent to $25 \mathrm{t} / \mathrm{ha}$ of manure); 8 - straw, $5 \mathrm{t} / \mathrm{ha}+\mathrm{N}_{115}$ (equivalent to $25 \mathrm{t} / \mathrm{ha}$ of manure); 9 - pre-sowing treatment of seeds with Rhizoagrin (background); $10-$ background $+\mathrm{N}_{140} \mathrm{P}_{95} \mathrm{~K}_{175}$ (equivalent to $25 \mathrm{t} / \mathrm{ha}$ of manure); 11 - background + manure, $25 \mathrm{t} / \mathrm{ha} ; 12$ - background + manure, $50 \mathrm{t} / \mathrm{ha} ; 13$ - background + OSV-1; 14 - background + OSV-2; 15 background + siderat; 16 - background + straw, 5 t/ha + $\mathrm{N} 115$ (equivalent to $25 \mathrm{t} / \mathrm{ha}$ of manure).

Plots with organic fertilizers were divided into two backgrounds. The first background was without fertilization (zero background). Against the second

\footnotetext{
* Corresponding author: Galina_83@list.ru
} 
background, the seeds inoculated on the day of sowing with Rizoagrin by the All-Russian Research Institute of Agricultural Microbiology created on the basis of Agrobacterium (A. radiobacter, strain 204) were sown.

Presowing seed treatment was manual: seeds were poured onto the tarpaulin, previously moistened with milk skim at the rate of $1.5-2.0 \%$ in relation to the seed weight, and thoroughly mixed with the required amount of the preparation at the rate of 500-600 g per hectare seed rate.

The efficiency of the fertilizers was assessed: mineral - Naa, Rsd and Kx; organic - litter manure, semi-rotten cattle, straw, green manure (vetch-oat mixture), sewage sludge from treatment facilities in Ulyanovsk.

Mineral fertilizers were applied under the pre-sowing cultivation according to the experimental scheme. Manure, straw, WWS and diatomite were sealed in clean fallow (May-June) with a heavy disc harrow to a depth of $10-12 \mathrm{~cm}$. Vetch-oats were cultivated as green manure. The spring vetch variety was Lgovskaya 22, the oat variety was Drug. The seeding rate was 3 million vetch seeds (150 kg/ha) and 2.5 million oat seeds $(70 \mathrm{~kg} / \mathrm{ha})$. The seeds were sown on the first ten days of May using nitro-phosphate (N15P15K15). The green manure was covered in 1-2 decades of July.

The repetition rate was four times, the sown area of the plots was $174 \mathrm{~m} 2(5.8 \times 30 \mathrm{~m})$, the counting area was $100 \mathrm{~m}^{2}(4 \times 25 \mathrm{~m})$.

The soil of the experimental site was leached heavy loamy chernozem. The humus content in the arable layer was $6.43-6.62 \%$, the content of total nitrogen was $0.26 \%$, mobile phosphorus - 214-228 $\mathrm{mg} / \mathrm{kg}$, exchangeable potassium - 101-117 $\mathrm{mg} / \mathrm{kg}$ (according to Chirikov), $\mathrm{pHKCl}$ - 6.3-6.8, hydrolytic acidity $1.20-1.29 \mathrm{mmol} / 100 \mathrm{~g}$ of soil, the amount of absorbed bases was 39.7-42.2 mmol/100 $\mathrm{g}$, the degree of saturation with bases was 96.9-97.2\%.

The weather conditions were different in the temperature regime and soil moisture and most fully reflected features of the Volga forest-steppe region, which had an impact on the yield of agricultural crops and made it possible to comprehensively assess the effect of the factors.

The field experiments, observations and laboratory analyzes were conducted by the generally accepted methods according to GOSTs.

Statistical analysis. The experimental data were processed by the methods of variance and correlationregression analyzes according to the method by B.A. Dospekhova (1985) [10]. Statistical processing of the results of field experiments was carried out in AGROS 2.06.

\section{Results and discussion}

A reflection of the conditions of mineral nutrition of plants, in addition to the level of productivity, is the nitrogen content both in grain and by-products [11]. The concentration of nitrogen in grain, straw and roots depends on the doses, types and forms of fertilizers, the level of crop productivity, weather conditions and a number of other factors that may affect plants during the ontogenesis.

Studies have shown that the aftereffect of organic fertilizers and pre-sowing seed treatment with Rhizoagrin increase the accumulation of stubble-root residues (STR), the main and by-products of spring wheat.

On average, over three years, the accumulation of SOC in the control option was $3.28 \mathrm{t} / \mathrm{ha}$, with the use of organic fertilizers (options 2-8) this indicator increased by $0.06-0.28 \mathrm{t} / \mathrm{ha}$. When spring wheat seeds were inoculated with Rhizoagrin (option 9), the amount of POC was $3.55 \mathrm{t} / \mathrm{ha}$, and against the background of the aftereffect of organic fertilizers combined with inoculation (options 10-16), it was 3.51-3.75 t/ha. The greatest amount of stubble and root residues was observed in options 4, 6, 12, 14 with increased doses of sewage sludge and manure (Table 1).

Table 1. Content of POC and nitrogen, $\mathrm{kg} / \mathrm{ha}$ (over three years)

\begin{tabular}{|c|c|c|c|c|}
\hline \multirow{2}{*}{ Option } & \multicolumn{4}{|c|}{ Content, kg/ha } \\
\cline { 2 - 5 } & roots & stubble & straw & grain \\
\hline \multicolumn{5}{|c|}{ Background 1 - zero } \\
\hline 1 & 13.8 & 3.4 & 16.8 & 70.2 \\
\hline 2 & 14.3 & 3.8 & 20.1 & 76.9 \\
\hline 3 & 14.7 & 4.7 & 23.0 & 81.4 \\
\hline 4 & 16.1 & 5.4 & 21.9 & 90.3 \\
\hline 5 & 14.7 & 4.4 & 19.9 & 84.1 \\
\hline 6 & 16.9 & 5.5 & 22.8 & 92.9 \\
\hline 7 & 17.1 & 4.2 & 20.3 & 81.9 \\
\hline 8 & 16.5 & 3.8 & 19.4 & 80.3 \\
\hline \multicolumn{5}{|c|}{ Background 2- seed inoculation } \\
\hline 1 & 16.1 & 4.6 & 21.2 & 83.8 \\
\hline 2 & 6.57 & 4.1 & 20.8 & 89.0 \\
\hline 3 & 16.6 & 5.4 & 22.5 & 89.8 \\
\hline 4 & 18.1 & 5.3 & 24.3 & 99.2 \\
\hline 5 & 16.2 & 5.1 & 23.5 & 93.5 \\
\hline 6 & 18.5 & 6.1 & 23.7 & 104 \\
\hline 7 & 18.3 & 4.7 & 23.5 & 91.8 \\
\hline 8 & 15.6 & 4.4 & 22.4 & 86.3 \\
\hline \multicolumn{7}{|c|}{}
\end{tabular}

The amount of by-products of spring wheat in the first year of the aftereffect of organic fertilizers increased by $0.36-0.74 \mathrm{t} / \mathrm{ha}$ (in the control $4.12 \mathrm{t} / \mathrm{ha}$ ). When using Rhizoagrin against the background of the aftereffect of organic fertilizers, the amount of straw varied from 4.83 to $5.17 \mathrm{t} / \mathrm{ha}$.

Along with the amount of plant residues, their chemical composition is of no small importance for the balance of nutrients in the soil, in particular, the content of nitrogen, phosphorus, and potassium. The higher their content (especially nitrogen), the more active their return to the soil. The analysis showed that the content of nutrients in POC increases after the application of organic fertilizers. Winter wheat root residues contained more nitrogen and phosphorus. There was more potassium in the stubble.

Together with the POC of spring wheat, $17-23 \mathrm{~kg} / \mathrm{ha}$ of nitrogen was supplied to the soil (options 1-8); with the combination of Rhizoagrin and the aftereffect of organic fertilizers, this value increased to $21-25 \mathrm{~kg} / \mathrm{ha}$ (options 9-16). At the same time, the largest amount of 
nutrients was due to the use of increased doses of manure and WWS.

The nitrogen content in grain and straw of spring wheat resulted from the mineral nutrition increased.

Inoculation of seeds with Rhizoagrin provides approximately the same nitrogen content as the application of $30 \mathrm{~kg} / \mathrm{ha}$ nitrogen of mineral fertilizers or the aftereffect of moderate doses of manure and WWS.

Nitrogen removal by grains and straw of spring wheat depended both on the concentration of nutrients in plants and the mass of the main and by-products. The maximum nitrogen removal was during the inoculation with Rhizoagrin against the background of the aftereffect of increased doses of WWS and manure (options 12, 14) (Table 2).

Table 2. Nitrogen removal by spring wheat with the use of a biological preparation and effects of organic fertilizers, average over 3 years

\begin{tabular}{|c|c|c|c|}
\hline Option & $\begin{array}{c}\text { Average, } \\
\text { kg/ha }\end{array}$ & $\begin{array}{c}\text { Removal by grain } \\
\text { and straw, kg/ha }\end{array}$ & $\begin{array}{c}\text { Removal for 1 ton } \\
\text { of grain, kg }\end{array}$ \\
\hline \multicolumn{4}{|c|}{ Background 1 - zero } \\
\hline 1 & 104.4 & 87.0 & 30 \\
\hline 2 & 115.3 & 97.0 & 31 \\
\hline 3 & 123.9 & 104.4 & 32 \\
\hline 4 & 133.8 & 112.2 & 32 \\
\hline 5 & 123.3 & 104.1 & 31 \\
\hline 6 & 138.2 & 115.7 & 33 \\
\hline 7 & 123.7 & 102.3 & 30 \\
\hline 8 & 120.8 & 99.88 & 30 \\
\hline \multicolumn{5}{|c|}{ Background 2- seed inoculation } \\
\hline 1 & 125.8 & 105.1 & 31 \\
\hline 2 & 132.7 & 120.8 & 32 \\
\hline 3 & 134.6 & 112.4 & 31 \\
\hline 4 & 146.9 & 123.5 & 32 \\
\hline 5 & 138.4 & 117.0 & 31 \\
\hline 6 & 152.5 & 127.9 & 34 \\
\hline 7 & 138.5 & 115.4 & 31 \\
\hline 8 & 128.8 & 108.7 & 31 \\
\hline
\end{tabular}

When comparing the effectiveness of organic fertilizers, the main criterion is productivity of crops. Various organic fertilizers and Rhizoagrin significantly influenced the yield of spring wheat (Table 3).

Against the first background, without the use of any means of chemicalization and biologization, the volume of grain yeild amounted to $2.88 \mathrm{t} / \mathrm{ha}$. As a result of applying N26P14K30 for spring wheat, an increase in the grain yield was $0.30 \mathrm{t} / \mathrm{ha}$.

Inoculation of spring wheat seeds with Rhizoagrin provided an increase in the grain yield (background 2). Sowing with inoculated seeds contributed to an additional grain yield of spring equal to $0.18 \mathrm{t} / \mathrm{ha}$.

The use of manure in doses of 25 and $50 \mathrm{t} / \mathrm{ha}$ had a positive effect on the grain yield. In relation to the zero background, its yield increased from 2.88 to $3.31-3.46$ t/ha, while the aftereffect of manure exceeded the direct effect of N26P14K30.

Inoculation of spring wheat seeds with Rhizoagrin had the highest aftereffect on the second crop rotation.

When sowing with inoculated seeds, the efficiency of $\mathrm{N} 26 \mathrm{P} 14 \mathrm{~K} 30$ and the aftereffect of manure in a dose of $25 \mathrm{t} / \mathrm{ha}$ were equivalent, and the double dose of manure exceeded the effectiveness of mineral fertilizers.
Table 3. Spring wheat yield when using fertilizers on various backgrounds, $t / h a$ (on average over three years)

\begin{tabular}{|c|c|c|c|}
\hline \multirow{2}{*}{ Option } & \multicolumn{3}{|c|}{ Yield } \\
\cline { 2 - 4 } & t/ha & \% & gain \\
\hline \multicolumn{3}{|c|}{ Background 1 - zero } \\
\hline 1. Control & 2.88 & 100 & - \\
\hline 2. $\mathrm{N}_{26} \mathrm{P}_{14} \mathrm{~K}_{30}$ & 3.18 & 110.4 & 0.30 \\
\hline 3. Manure 25 t/ha & 3.31 & 114.9 & 0.43 \\
\hline 4. Manure 50 t/ha & 3.46 & 120.1 & 0.58 \\
\hline 5. OSV 12,5 t/ha & 3.38 & 117.4 & 0.50 \\
\hline 6. OSV 25 t/ha & 3.52 & 122.2 & 0.64 \\
\hline 7. Green manure & 3.36 & 116.7 & 0.48 \\
\hline 8. Starw+ $\mathrm{N}_{20}$ & 3.28 & 113.9 & 0.40 \\
\hline \multicolumn{2}{|c|}{ Average } & $\mathbf{3 . 3 0}$ & \multicolumn{1}{c|}{} \\
\hline \multicolumn{2}{|c|}{ Background 2- seed inoculation } \\
\hline 1. Control & 3.38 & 100 & - \\
\hline 2. N26 ${ }_{14 K} \mathrm{~K}_{30}$ & 3.56 & 105.3 & 0.18 \\
\hline 3. Manure 25 t/ha & 3.61 & 106.8 & 0.23 \\
\hline 4. Manure 50 t/ha & 3.83 & 113.3 & 0.45 \\
\hline 5. OCB 12,5 t/ha & 3.77 & 111.5 & 0.39 \\
\hline 6. OSV 25 t/ha & 3.80 & 112.4 & 0.42 \\
\hline 7. Green manure & 3.69 & 109.2 & 0.31 \\
\hline 8. Straw+ $\mathrm{N}_{20}$ & 3.48 & 102.9 & 0.10 \\
\hline Average & $\mathbf{3 . 6 4}$ & & $\mathbf{0 . 3 0}$ \\
\hline
\end{tabular}

LSD 05 0,235 (2006), 0,201 (2007), 0,185 (2008)

The use of sewage sludge as an organic fertilizer applied at the beginning of the crop rotation had a positive impact on the yield. Against the zero background, the aftereffect of $12.5 \mathrm{t} / \mathrm{ha}$ of $\mathrm{WW}$ surpassed the effect of mineral fertilizers, and when using their double dose, a further increase in the grain yield was observed. In both doses of WWS, their aftereffect was equivalent to the one of manure. When sowing with inoculated seeds, the aftereffect of both doses of sewage sludge was the same and corresponded to the use of manure under the first crop, but exceeded the effect on the yield of mineral fertilizers applied to the crop in a dose of N26P14K30.

The aftereffect of green manure plowed under the first crop had a positive effect. On average, over three years, green manure had a positive aftereffect on its yield ment. The increments ranged from 0.31 to $0.48 \mathrm{t} / \mathrm{ha}$. The maximum aftereffect was obtained for the zero background, although the overall yield level when growing spring wheat with seed inoculation was higher.

When assessing the aftereffect of straw introduced under the first crop rotation, it was found that its effect, together with the use of nitrogen fertilizer in a dose of $\mathrm{N} 20$, was positive and ensured the production of $3.28 \mathrm{t} / \mathrm{ha}$ of grain at the zero background, which corresponded to the direct action of N26P14K30. As a result of inoculation of spring wheat seeds with Rhizoagrin against the straw background, the maximum grain yield was obtained, and the aftereffect of straw and N20 applied was equivalent to the direct effect of complete mineral fertilization.

An increase in the yield due to the application of organic fertilizers ranged from 0.3 to $0.64 \mathrm{t} / \mathrm{ha}$, or 10.4-22.2 \%. With the aftereffect of green manure, straw as organic fertilizers and the 
use of mineral fertilizers, the yield of spring wheat increased by 10.4-16.7 \%. Increased doses of manure and WWS contributed to the yield of 3.46-3.52 t/ha. With pre-sowing seed treatment with Rhizoagrin, the yield of spring wheat increased by $0.5-0.95 \mathrm{t} / \mathrm{ha}$.

The content of crude protein varied from 13.8 to $15.6 \%$ (Table 4). At all backgrounds, the application of N26P14K30 did not increase the protein content. Against the zero background, according to the aftereffect of both doses of sewage sludge, the protein content increased to $14.2 \%$, the grain corresponded to the first class. Inoculation of seeds had a positive effect on the protein content. A more significant increase in protein due to the aftereffect of manure and sewage sludge applied in double doses.

Table 4. Spring wheat grain quality when using fertilizers at various backgrounds (average over 3 years)

\begin{tabular}{|c|c|c|c|c|c|c|}
\hline \multirow[b]{2}{*}{ 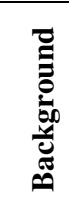 } & \multirow[b]{2}{*}{ 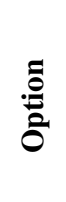 } & \multicolumn{2}{|c|}{ Weight, \% } & \multirow[b]{2}{*}{ 光 } & \multirow[b]{2}{*}{ 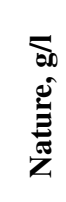 } & \multirow{2}{*}{ 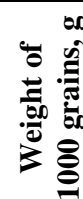 } \\
\hline & & 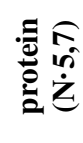 & $\begin{array}{l}\text { Crude } \\
\text { gluten }\end{array}$ & & & \\
\hline \multirow{8}{*}{ 웜 } & 1 & 13.9 & 24.6 & 88 & 752 & 38.7 \\
\hline & 2 & 13.8 & 24.8 & 81 & 769 & 38.8 \\
\hline & 3 & 14.0 & 25.2 & 81 & 775 & 39.1 \\
\hline & 4 & 14.9 & 26.8 & 83 & 765 & 39.2 \\
\hline & 5 & 14.2 & 25.6 & 78 & 773 & 39.6 \\
\hline & 6 & 15.1 & 24.5 & 85 & 768 & 39.4 \\
\hline & 7 & 13.9 & 25.0 & 87 & 760 & 39.2 \\
\hline & 8 & 14.0 & 25.2 & 87 & 758 & 38.9 \\
\hline \multicolumn{2}{|c|}{ Average } & 14,2 & 25.2 & 84 & 765 & 39.1 \\
\hline \multirow{8}{*}{ 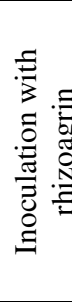 } & 1 & 14.1 & 24.4 & 82 & 766 & 39.0 \\
\hline & 2 & 14.3 & 24.7 & 78 & 779 & 41.4 \\
\hline & 3 & 14.2 & 25.6 & 73 & 786 & 41.9 \\
\hline & 4 & 14.8 & 24.8 & 78 & 774 & 41.0 \\
\hline & 5 & 14.1 & 25.4 & 74 & 783 & 41.8 \\
\hline & 6 & 15.6 & 24.5 & 79 & 774 & 40.3 \\
\hline & 7 & 14.2 & 25.6 & 80 & 769 & 40.9 \\
\hline & 8 & 14.1 & 25.4 & 81 & 771 & 40.2 \\
\hline \multicolumn{2}{|c|}{ Average } & 14,4 & 25.1 & 78 & 775 & 40.8 \\
\hline \multicolumn{2}{|c|}{$P, \%$} & 2.8 & 2.4 & 2 & 0.6 & 1.1 \\
\hline \multicolumn{2}{|c|}{$\begin{array}{c}L S D_{05} \\
(\text { Option) } \\
\end{array}$} & 0.86 & - & 5 & 12 & 1.3 \\
\hline \multicolumn{2}{|c|}{$\begin{array}{c}L S D_{05} \\
\text { (Background) }\end{array}$} & - & 1.4 & 2 & 4 & 0.4 \\
\hline \multicolumn{2}{|c|}{$\begin{array}{c}L S D_{05} \\
\text { (Option) }\end{array}$} & 0.36 & 1.0 & 3 & 7 & 0.7 \\
\hline \multicolumn{2}{|c|}{$\begin{array}{c}L S D_{05} \\
\text { (interaction) }\end{array}$} & 0.85 & 3.5 & 5 & 12 & - \\
\hline
\end{tabular}

The spring wheat grain grown with various combinations of chemicals and biologization agents accumulated 24.4 to $26.8 \%$ of crude gluten. According to GOST R 52554-2006, the grain belongs to the third quality class. With a change in the conditions of mineral nutrition of spring wheat plants grown at the zero background, due to the aftereffect of manure in a dose of $50 \mathrm{t} / \mathrm{ha}$, there was a trend to an increase in the content of crude gluten.

The deformation index of gluten determined on the IDK device varied from 74 to 98 units. Its maximum value is typical for grain produced without the use of fertilizers or with low doses of nitrogen fertilization.

According to the IDC, the grain of winter wheat I had values varying from 75 to 88 units. Improvement of nitrogen nutrition conditions due to mineral fertilizers or manure and sewage sludge decreased the IDC index both against the zero background and as a result of seed inoculation with a biological product.

During the seed inoculation, the grain of spring wheat had lower IDC values equal to 74-82 units.

The mass of 1,000 grains varied from 39 to $42 \mathrm{~g}$. With the improvement of mineral nutrition, the mass of 1,000 grains increased in comparison with the control one. The nature value varied within the range of $752-786 \mathrm{~g} / \mathrm{l}$.

\section{Conclusion}

Thus, the amount of by-products of spring wheat in the first year of the aftereffect of organic fertilizers increased in comparison with the control by $0.36-0.74 \mathrm{t} / \mathrm{ha}$. Together with the POC of spring wheat, $17-23 \mathrm{~kg} / \mathrm{ha}$ of nitrogen entered the soil with a combination of Rhizoagrin and organic fertilizers; this value increased to 21-25 kg/ha. Nitrogen removal was $70.27 \mathrm{~kg} / \mathrm{ha}$; in options (2-8) this indicator increased by $6.69-22.66 \mathrm{~kg} / \mathrm{ha}$, and when combined with Rhizoagrin - by $13.55-33.85 \mathrm{~kg} / \mathrm{ha}$. The yield gain from the aftereffect of organic fertilizers was $0.3-0.64 \mathrm{t} / \mathrm{ha}$, or 10.4-22.2 \%. Increased doses of manure and sewage sludge contributed to the yield of 3.46-3.52 t/ha. With pre-sowing seed treatment with Rhizoagrin, the yield of spring wheat increased by $0.5-0.95 \mathrm{t} / \mathrm{ha}$.

\section{References}

1. A.A. Zavalin, N.S. Almetov, V.V. Berdnikov, G.G. Blagoveshchenskaya, The effectiveness of the use of biological products in crop rotation, Agrochem., 6, 28-37 (2010)

2. A.L. Ivanov, A.A. Zavalin, Priorities of scientific support of agriculture, Agricult., 7, 3-6 (2010)

3. A.Kh. Kulikova, S.N. Nikitin, G.V. Saidyasheva, The influence of fertilizers on the content and balance of humus in leached chernozem during the cultivation of crops in grain-steam crop rotation, Agrochem., 12, 7-15 (2017)

4. A. Kulikova, S. Nikitin, G. Saidyasheva, A. Toigildin, Res. J. of Pharmac., Biol. and Chem., Sci., 10 (2019)

5. A.A. Zavalin, V.V. Berdnikov, N.S. Almetov, The effectiveness of the use of biological products for 
spring wheat, Bull. of the Russ. Acad. of Agricult. Sci., 5, 76-78 (2004)

6. A.A. Zhuchenko, Adaptive agricultural intensification strategy (Pushchino, 1994), 148 p.

7. A. Zavalin, L. Vinogradova, T. Dukhanina, A. Vaulin, M. Chistotin, D. Sologub, M. Gabibov, P. Lekomtsev, A. Pasynkov, Plant Microbial weight Interactions: Positive interactions in relation to crop production and utilization, Aspects of Appl. Biol., 63 (2001)

8. A.A. Alferov, L.S. Chernova, A.A. Zavalin, V.K. Chebotar, Efficiency of endophite drugs and nitrogen fertilizers, Bull. of agricult., Sci., 5, 21-24 (2017)

9. J. Patel, G. Archana, Plant and Soil (2017)

10. B.A. Dospekhov, Field experiment technique (Moscow, 1985), $351 \mathrm{p}$.

11. N.S. Almetov, N.V. Goryachkin, Kh.Z. Nazmiev, L.N. Samoilov, A.A. Zavalin, The effectiveness of the use of mineral fertilizers and the biological product flavobacterin on spring wheat, Fertil., 5, 3435 (2012) 